\section{Environment International}

Volume 33, Issue 1 , January 2007, Pages 27-33

http://dx.doi.org/10.1016/j.envint.2006.06.020

(c) 2006 Elsevier Ltd All rights reserved
Archimer, archive institutionnelle de l'Ifremer http://www.ifremer.fr/docelec/

\title{
Marine water quality assessment using transplanted oyster larvae
}

\author{
F. Quiniou ${ }^{a}$, G. Damiens ${ }^{b}$, M. Gnassia-Barellib ${ }^{b}$ A. Geffard ${ }^{c}$, \\ C. Mouneyrac ${ }^{d}, H$. Budzinski ${ }^{e}$ and M. Roméo ${ }^{b, *}$
}

\begin{abstract}
${ }^{a}$ Département Biogéochimie et Ecotoxicologie IFREMER-Centre de Brest, B.P. 70, 29280 PLOUZANÉ, France

${ }^{\mathrm{b}}$ UMR 1112 INRA-UNSA R.O.S.E., Faculté des Sciences, Parc Valrose, BP 71, 06108 NICE Cedex 2, France

${ }^{\circ}$ EA 2069 URVVC, Laboratoire d'Eco-Toxicologie, Faculté des Sciences Exactes et Naturelles, Moulin de la Housse BP 1039, 51687 REIMS Cedex, France

${ }^{\mathrm{d}}$ Centre d'Etude et de Recherche sur les écosystèmes aquatiques (CEREA), IBEA/UCO, 3 Place André Leroy, BP 10808, 49008 ANGERS Cedex 01, France and Service d'Ecotoxicologie, SMABISOMER, Faculté des Sciences, 2 rue de la Houssinière, BP 92208, 44322 NANTES Cedex 3, France e LPTC Université de Bordeaux I, 3405 TALENCE, France
\end{abstract}

*: Corresponding author : romeo@unice.fr

\begin{abstract}
:
Active bio-monitoring in terms of biomarkers was attempted using Crassostrea gigas larvae produced in the laboratory and transplanted using special containers to two sites at the entrance $(A)$ and inner part (P) of the harbour of Arcachon (French Atlantic Coast). The larvae were kept in the medium for $48 \mathrm{~h}$. Their physiological status and their biomarker levels : acetylcholinesterase AChE, catalase CAT and glutathione S-transferase GST activities were determined together with metallothionein MT and Thiobarbituric Acid Reactive Substances TBARS concentrations. Copper and PAH (polycyclic aromatic hydrocarbon) concentrations were determined in the exposed larvae and in the sediments collected under the containers. Cadmium, lead and zinc could be also analyzed in the sediments. Toxicity tests demonstrate that the larvae are in better physiological conditions in A compared to $\mathrm{P}$. Larvae transplanted in the inner harbour $(P)$ present relatively high GST activity $(869.1 \pm 39.3 \mathrm{nmol}$ $\mathrm{min}^{-1} \mathrm{mg}$ protein $\left.{ }^{-1}\right)$, TBARS $\left(2.74 \pm 0.19 \mathrm{nmol} \mathrm{mg}\right.$ protein $\left.{ }^{-1}\right)$, compared to those exposed at the harbour entrance (A). Copper measured in the sediments $\left(65 \pm 1 \mathrm{mg} \mathrm{kg}^{-1}\right.$ d.w.) collected under the cages at $P$ is higher than at $A$. Larvae placed in $A$ present higher total $P A H$ concentrations compared to the inner part. The data tend to reveal a lower copper and higher PAH contamination in $A$ than in $P$. Therefore larvae, developing in the natural medium, show different responses according to their immersion sites. These responses, obtained within $48 \mathrm{~h}$, may be related to the chemical contamination of the environment and may be used for seawater quality assessment in future studies.
\end{abstract}

Keywords: Crassostrea gigas larvae; Active bio-monitoring; Biomarkers; Trace metals; PAHs 


\section{Introduction}

Embryos and larvae of oysters of the genus Crassostrea and mussels of the genus Mytilus have already been proposed as sentinel organisms for marine ecotoxicological tests for the purpose of assessing seawater quality, because they are very sensitive to pollutants and provide rapid responses (Stebbing et al., 1980 ; His et al., 1997, 1999). Laboratory experiments have also been carried out to evaluate the effect of various pollutants on oyster larvae (carbofuran and malathion, Damiens et al., 2004; copper and cadmium, Damiens et al., 2006) by measuring biochemical biomarkers.

Laboratory studies, however, cannot accurately simulate natural conditions. The purpose of this paper was, thus, to perform active bio-monitoring using oyster embryolarval organisms transplanted at sea. Active bio-monitoring is based on comparing chemical and/or biological properties of samples collected from one population which, after randomization and translocation, have been exposed to different environmental conditions at monitoring sites (de Kock and Kramer, 1994). Active biomonitoring is now commonly used to evaluate sea water quality using biomarkers measured in transplanted mussels (Roméo et al., 2003 a and b; Andral et al., 2004). Few studies concern bio-assays (i.e. toxicity tests) on embryo-larval development performed in the field (with oyster larvae: Geffard et al., 2001 and with sea urchin larvae: Beiras et al., 2001). Therefore, it seemed interesting to perform this field experiment using biomarkers, constituting an early warning system, at this stage of development which is very sensitive to the quality of the environment.

The study took place at the harbour of Arcachon (SW of France), located in the south of the Arcachon Bay (Atlantic coast) which is devoted to oyster farming. The harbour of Arcachon has space for 2400 medium-size yachts, $80 \%$ of which never leave their berths, despite being inhabited during the summer. The boats are a source of growing pollution, especially dissolved copper concentrations which have been increasing in harbours since the banning in 1982 of TBT and all organotin-based products on boats under $25 \mathrm{~m}$ along the entire French coastline.

Crassostrea gigas "D" larvae were obtained in the laboratory and placed in special containers at the entrance (A) and the inner part of the harbour (P) of Arcachon (Fig. 1) at the beginning of summer (July 2002 and end of June 2004). After collecting the "in situ” exposed larvae, their biomarker levels (glutathione S-transferase GST, catalase CAT and acetylcholinesterase AChE activities and Thiobarbituric Acid Reactive Substances TBARS and Metallothionein MT concentrations) were measured. The physiological status of the obtained larvae was evaluated in the laboratory by determining the $\mathrm{CuSO}_{4}$ concentration producing $50 \%$ of abnormal larvae (EC50). Copper and Polycyclic Aromatic Hydrocarbons (PAHs) were measured in the exposed larvae. The profile of 16 priority pollutant PAHs recommended by the US Environmental Protection Agency (EPA) was determined in the larvae. Measuring the $\mathrm{PAH}$ profile or fingerprint can give information on their source (pyrolytic, diagenetic and petroleum hydrocarbons, Baumard et al., 1998). Moreover, metals, PAHs and PCBs (polychlorobiphenyls) levels were determined in the sediments collected under the larvae containers. Sediments represent a major compartment for metal storage in aquatic environments (Förstner and Wittmann, 1979); although the total trace metal concentrations in sediments give a somewhat useful determination of metal pollution, such measurements do not predict the toxicity of these pollutants regarding aquatic 
animals. The ecotoxicological risk posed by contaminated sediment will depend on metal bioavailability towards the water column. Desorption tests have been proposed to assess the fraction of sediment-bound metals likely to be remobilized (Geffard et al., 2005). These tests were performed in the sediments collected under the larvae containers located at $\mathrm{A}$ and $\mathrm{P}$ sites.

\section{Materials and methods}

\subsection{Obtaining larvae}

The oysters came from the bivalve hatchery of "Barfleur". In the laboratory, oysters were induced to spawn by thermal stimulation (His et al., 1997, 1999; Quiniou and Toularastel, 1991; Quiniou et al., 2005). Females in the laying process were isolated in 1 liter of filtered reference sea water (FRSW), the salinity of which was adjusted to 30 and which was then filtered through $0.22 \mu \mathrm{m}$ membrane). Spawning males were put in $500 \mathrm{~mL}$ of FRSW, to obtain a sperm-dense solution. The oocytes and sperm of different oysters were observed, after sieving through $100 \mu \mathrm{m}$ for oocytes and $32 \mu \mathrm{m}$ for spermatozoa, under an inverted microscope, and the most reproductive pair (regular oocytes and very mobile spermatozoa) was selected for the experiment. The oocytes were fertilized by the sperm-dense solution (up to 10 spermatozoa per 1 oocyte). Fifteen minutes after fertilization, the embryo density was determined and adequate volumes prepared in vials were filled with $100 \mathrm{~mL}$ of FRSW, until their immersion at sites A and $\mathrm{P}$ in the harbour of Arcachon (Fig. 1), in order to obtain a final concentration of 30000 larvae per liter inside $2 \mathrm{~L}$ special containers described below. Embryos from the same pool were placed in $30 \mathrm{~mL}$ FRSW beakers in order to assess their sensitivity to increasing $\mathrm{CuSO}_{4}, 5 \mathrm{H}_{2} \mathrm{O}$ concentrations $\left(0,20,40,60\right.$ and $\left.80 \mu \mathrm{g} \mathrm{L}^{-1}\right)$ in the laboratory for $24 \mathrm{~h}$ at $25^{\circ} \mathrm{C}$ and salinity 30. Abnormal larvae were counted and an EC50 was determined both graphically and by probit calculation.

The containers for the larvae were built from 2-litre flasks of low-density polyethylene. The bottom of each bottle was cut away and the opening covered with polyamide gauze of $30 \mu \mathrm{m}$ mesh. The gauze was stuck by heat-soldering, in order to avoid any glues, since all the glues tested were found to be toxic to bivalve embryos (Geffard et al., 2001). To allow the water to circulate through the bottle, the top opening was equally covered with gauze fastened by a sealing ring and an open screw cap. According to Geffard et al. (2001), the retention period of water in the containers was about 15 min, estimated with a solution of neutral red.

A preliminary experiment was attempted in July 2002. The larvae were kept in the containers for $48 \mathrm{~h}$. A more complete experiment was carried out in June 2004. The duration of toxicity tests with $\mathrm{CuSO}_{4}$ in the laboratory was $24 \mathrm{~h}$ at room temperature $\left(24-25^{\circ} \mathrm{C}\right.$ ) whereas embryos were kept in the containers at the two sites of Arcachon harbour for $48 \mathrm{~h}$. The containers (two-litre flasks placed at each site) were put into nets and ballasted so as to keep them at a depth of 1 meter under the surface where abiotic parameters $\left(\mathrm{pH}\right.$, dissolved $\mathrm{O}_{2}$, temperature, salinity, redox potential) are measured. At the end of the experiment, the containers were sampled and the larvae were collected using a $32 \mu \mathrm{m}$ sieve. After filtration, among the 2L flasks containing larvae, fifteen were split into 5 pools for biomarker determinations, two containers into a pool for copper analysis, two into a pool for MT determination and two into a pool for PAH determination. All together, eight pools were obtained. Larvae density was verified and 
the number of abnormal larvae from the two sites (A) and (P) determined on aliquots from the 8 pools. The larvae were frozen at $-80{ }^{\circ} \mathrm{C}$ until analysis.

\subsection{Biomarker measurement}

The larvae were homogenized in a buffer (TRIS $50 \mathrm{mM}, \mathrm{NaCl} 150 \mathrm{mM}, \mathrm{pH}$ 7.4, 0.1 $\mathrm{mM}$ antiprotease cocktail, $1 \mathrm{mM}$ DTT (dithiothreitol)) in a $1 / 3 \mathrm{w} / \mathrm{v}$ (weight/volume) ratio, using a Potter-Elvehjem glass homogenizer fitted with a teflon pestle. The homogenates were then centrifuged for $25 \mathrm{~min}$ at $9000 \mathrm{~g}$. All procedures were carried out at $0-4{ }^{\circ} \mathrm{C}$. Aliquots of the supernatant (called S9 fraction) were frozen at $-80^{\circ} \mathrm{C}$ until analysed. All determinations of enzyme assays, total protein and TBARS levels were performed on S9 fractions. The procedure is extensively described in Damiens et al. (2004). For metallothionein determination, S9 was centrifuged (25,000 g, 55 min at 4 $\left.{ }^{\circ} \mathrm{C}\right)$. MT was isolated from an aliquot of the supernatant, by a second centrifugation $\left(15,000 \mathrm{~g}, 10 \mathrm{~min}\right.$ at $4{ }^{\circ} \mathrm{C}$ ) after heating for $15 \mathrm{~min}$ at $75^{\circ} \mathrm{C}$. This supernatant, containing the MT, was frozen at $-80{ }^{\circ} \mathrm{C}$ until analysis. The MT assay was performed by differential pulse polarography. The procedure is described in Damiens et al. (2006). MT results are given as $\mu \mathrm{g}$ MT mg protein ${ }^{-1}$ or $\mu \mathrm{g} \mathrm{MT} \mathrm{g}^{-1}$.

\subsection{Metal analysis in larvae and sediments}

S9 fractions of in situ exposed larvae were digested with nitric acid (65\%, Merck Suprapur) in a microwave oven (CEM MDS $81 \mathrm{D})$. Copper analysis was carried out on the resulting solutions by means of flameless atomic absorption spectrophotometry (GBC 904 AA + GBC GF 3000). Deuterium background correction was used. The analytical procedure was calibrated against a standard reference material, namely lobster hepato-pancreas (TORT-2 provided by the National Research Council of Canada). The result (102 $\pm 4 \mu \mathrm{g} / \mathrm{g}$ d.w.; $\mathrm{n}=7$ ) was in agreement with the certified value for copper (106 $\pm 10 \mu \mathrm{g} / \mathrm{g}$ d.w.).

Superficial sediments were sampled using an Ekmann - Birge bottom sampler, and the first five centimetres were collected with a horn spoon and placed immediately in polypropylene containers. For desorption tests, boxes were filled to the brim to eliminate air. Samples were then transported to the laboratory with icepacks in an isothermal container. Samples for desorption tests were stored in the dark, at $4^{\circ} \mathrm{C}$ and treated within a week of collection.

All desorption tests (in triplicate) were carried out according to Lebesnerais (1985). The conditions of desorption represent those existing the digestive tract of oysters, concerning the $\mathrm{pH}$ and the mean time of food in the digestive tract. Each sediment sample (500 mg) was dispersed into a buffer at pH 4 (20 mL; prepared with 1\% acetic acid and adjusted to appropriate $\mathrm{pHs}$ by adding suprapure ammonia). The contact time was $2 \mathrm{~h}$ at ambient temperature $\left(19-21^{\circ} \mathrm{C}\right)$. Then sediments were recovered by centrifugation (1000 g for 10 minutes). The percentage of desorption was calculated from the concentrations of metals in initial and treated sediments. Total and desorbed samples were analysed by flame AAS for $\mathrm{Cu}$ and $\mathrm{Zn}$ and flameless AAS with Zeeman effect for $\mathrm{Cd}$ and $\mathrm{Pb}$, after digesting the dried sediment with $2: 5(\mathrm{~V}: \mathrm{V}) 33 \% \mathrm{HCl}$ and 65 $\% \mathrm{HNO}_{3}$. The analytical method was checked by analyzing standard reference material : MESS-2, marine sediment (National Research Council Canada), the results (displayed 
in Table 4) are in good agreement with the certified values except for lead which shows lower concentrations.

\subsection{Organic analysis in larvae and sediments}

The concentrations of 16 polycyclic aromatic hydrocarbons (PAHs) and of Methyl-Naphthalenes and Methyl-Phenanthrenes were determined in larvae using gas chromatography combined with mass spectrometry, based on a protocol described by Baumard and Budzinski (1997). The determination of PAHs in the sediments was performed in the Environment Laboratory of Nice (France), this laboratory is accredited (COFRAC) by the French Ministry of the Environment. Sediments were submitted to microwave extraction using an acetone: petroleum ether (50:50) mixture, the extract was then purified using a $\mathrm{CN}$ cyanopropyle/SiOH cartridge, the determination was performed using HPLC coupled with a variable wavelength fluorometer (1100 Agilent), the detection threshold was 0.001 ng. A standard reference sediment IMR-109 purchased from the Community Bureau of Reference (Commission of European Communities) was also analysed and the results are within the range given by the supplier (Table 5). For PCBs, the same extraction method as that for PAHs was performed. The extracted sediment was purified on a NAN cartridge. The determination was performed using gas chromatography coupled with a specific ion scanning mass spectrometer (6890 AGILENT 5973 MSD). The detection threshold was 0.001 ng. A sediment (Harbour sediment 536) provided by the International Atomic Energy Agency of Monaco (IAEA) was also analyzed as a standard reference material. The results of the analyses are shown in Table 6. 


\section{Results}

\subsection{Experiment of July 2002}

The results of July 2002 are shown in Table 1; the water temperature was $23^{\circ} \mathrm{C}$ and the salinity 32.5 at both sites. Biomarker measurements (AChE activity , TBARS and MT concentrations) were carried out in the pool of larvae from both sites (A) and (P) due to the low biomass obtained. The protein level is lower in $\mathrm{P}$ than in A. AChE activity seems to be inhibited in larvae from $\mathrm{P}$ compared to those from $\mathrm{A}$, whereas TBARS increase, MT concentrations do not vary very much.

\subsection{Experiment of June 2004}

The abiotic parameters, measured in the surrounding waters of A and P in June 2004, are shown in Table 2. Salinity and water temperature are the same at the two sites, the dissolved oxygen is lower in $\mathrm{P}$ than in $\mathrm{A}$ whereas $\mathrm{pH}$ is higher. The redox potential is higher in the water column at site $\mathrm{A}$ than at $\mathrm{P}$.

The results of the toxicity tests with $\mathrm{CuSO}_{4}$ performed in June 2004 are shown in Fig. 2A. From $20 \mu \mathrm{guSO}_{4} \mathrm{~L}^{-1}$, the number of larvae blocked at the embryo stage and larvae with abnormal mantles or shells increases with the amount of copper concentration in the medium. EC50 (effective concentration giving 50\% abnormal larvae) was evaluated both graphically (Fig. 2B) and by probit, it is equal to $41.99 \pm$ $1.73 \mu \mathrm{g} \mathrm{CuSO}_{4} \mathrm{~L}^{-1}$ (Confidence interval: at $P<0.05$ : $38.18-45.11 \mu \mathrm{guSO}_{4} \mathrm{~L}^{-1}$ ). Fig. $3 \mathrm{~A}$ represents the categories of abnormal larvae for in situ exposed larvae; larvae developing in the containers located at $\mathrm{P}$ present a higher number of larvae blocked at the embryo stage and larvae with abnormal mantles or shells. Fig. 3B displays the percentage of abnormal larvae in the containers located at A (41.71 $\pm 2.59 \%)$ and $\mathrm{P}$ $(58.43 \pm 6.14 \%)$. This demonstrates that larvae are in better physiological conditions in A compared to $P$.

The results of the biochemical and chemical analyses performed on the larvae immersed at A and P in June 2004 are shown in Table 3. The larva biomass was higher than in 2002. In 2004, the protein and biomarker levels are not significantly different except for GST activity and TBARS levels which are higher in $\mathrm{P}$ than in A. The protein as well as the MT and copper concentrations in larvae tend to increase from A to $\mathrm{P}$ whereas AChE activity tends to be lower in P. Organics in larvae show a higher tendency in A than in P. Naphthalene is the main PAH present, other hydrocarbons shown in Table 3 are present at concentrations $<20 \mathrm{ng} \mathrm{g}^{-1}$, methyl-naphthalenes are non negligible whereas methyl-phenanthrenes are not detectable.

Table 4 displays the results of metal concentrations in sediments from $\mathrm{A}$ and $\mathrm{P}$, all metals are higher in sediments from $\mathrm{P}$ than in those from $\mathrm{A}$, the difference is significant for copper and zinc. Significant desorption of metals with acid treatment of the sediments occurs only for cadmium, the percentage of desorption is 34\% for sediment A and $11 \%$ for sediment $\mathrm{P}$.

Table 5 shows PAH concentrations in the sediments collected from A and P. They are not significantly different in sediment A compared to sediment P. No differences are noted in PCB concentrations in sediments from A and P (Table 6). 


\section{Discussion}

Previous experiments carried out in laboratory conditions evaluated the effects of chemicals on oyster larvae in terms of biomarkers (Damiens et al., 2004; 2006). The rationale for in situ testing is to eliminate artificial laboratory conditions affecting the real toxicity and bioavailability of contaminants in order to improve simulation of the natural environment. The main constraint, when using eggs fertilized in the laboratory and allowing them to develop in the field, was to obtain sufficient biological material in order to perform numerous analyses which are necessary to validate the chosen tools (i.e. biomarkers). In the preliminary experiment, conducted in July 2002, the collected biological material (i.e. obtained larvae) only demonstrated the possibility of measuring some biomarkers (AChE activity, TBARS and MT concentrations) in transplanted larvae. In June 2004, the biological material collected was sufficient to perform toxicity tests, copper analyses, PAH analyses and AChE, CAT and GST activities, TBARS and MT concentrations. The toxicity tests, carried out in the laboratory using $\mathrm{CuSO}_{4}$, show EC50 reaching ca $42 \mu \mathrm{guSO}_{4} \mathrm{~L}^{-1}$ indicating that the couple used for this experiment was in fair physiological condition: the sensitivity of larvae is within the average normal values obtained in assays conducted with oysters matured in hatcheries: $\mathrm{EC}_{50}=32.88 \pm$ $12.15 \mu \mathrm{g} \mathrm{CuSO}_{4} \mathrm{~L}^{-1}$ (Quiniou et al., 2005). The percentage of abnormal larvae (Fig. 3B) is different between $\mathrm{A}$ and $\mathrm{P}$, the water surrounding A inducing ca $40 \%$ abnormalities and that for P inducing ca $60 \%$ abnormalities. Geffard et al. (2001) reported embryolarval bioassays of Crassostrea gigas and Mytilus galloprovincialis in the same area (Arcachon harbour), at the end of June, when the sea water temperature reached 19 $22.4{ }^{\circ} \mathrm{C}$. These authors observed $52 \%$ abnormal larvae in the location we called $\mathrm{P}$ whereas it was $14.7 \%$ at the entrance to the Arcachon harbour (A). Our results from June 2004 show a higher percentage of abnormalities than the above-mentioned studies and fewer differences between the two locations. The two experiments described in the present paper occurred in the same salinity conditions: $32 \pm 1$ but the temperature was lower in June 2004 than in July 2002. In both cases, salinity and temperature are consistent with a good embryo-larval development. A salinity of 32 is within the range tolerated by the larvae (Damiens et al., 2004). If the temperature of $24{ }^{\circ} \mathrm{C}$ allows development until the D-larvae stage within $24 \mathrm{~h}$, in colder water (such as that displayed in Table 2), more time is necessary to reach this stage. As regards the dissolved oxygen, the higher level in A than in $\mathrm{P}$ (Table 2) demonstrates that the waters from site A are less confined than those from P. The quality of sea water, rather than hydrological conditions, is thus responsible for the observed abnormalities (Fig. 3B) in the containers immersed in A and particularly in P.

The biomarker measurements confirmed the differences observed above between the two sites during the periods of study. Biomarker levels measured in the larvae tend to differ between 2002 and 2004. This may be related to the fact that larvae came from different parents (couple of July 2002 and that of June 2004). Stebbing et al. (1980) suggested that genetic differences may occur, subsequently causing different biochemical responses. In July 2002 (Table 1), MT levels do not vary between A and P whereas AChE activity measured in the larvae is lower and TBARS higher in P than in A. In June 2004 (Table 3), the same tendency is found for AChE activity and TBARS levels. The significantly higher levels of GST and TBARS in P than in A may be associated with organics but also with metals and in particular copper. This metal as well as metallothionein tend to be present in higher concentrations in larvae from P. The 
concentration of copper in larvae from $\mathrm{P}$ is higher than that reported for larvae (from the same origin) used as controls in copper uptake experiment: 20 to $26 \mathrm{ng} \mathrm{Cu} / \mathrm{mg}$ protein (Damiens et al., 2006). In these control larvae, the distribution of copper was evaluated and demonstrated that $80 \%$ of copper are associated to the soluble fraction (unpublished data). Sediments, which are a receptacle for pollutants, present higher copper concentrations in P. Larvae kept only $48 \mathrm{~h}$ in the medium did not register a great copper accumulation but an early warning system such as the GST activity and lipid peroxidation may be evoked. Canesi et al. (1999) reported high GST activities in mussels experimentally exposed to copper. Roméo et al. (2003 a) reported high levels of copper associated with high GST activities in mussels transplanted for one month into a Mediterranean harbour. Moreover the induction of lipid peroxidation by copper is wellknown in molluscs (Viarengo, 1989). Copper may come from the use of antifouling paints and is found in sediments at high concentrations associated with relatively high zinc concentrations in P (Table 4) and may be related to dockyard activities. Long et al. (1995) and Alzieu and Quiniou (2001) defined the "potential toxicity" of sediments (effects range-low : ER-L and effects range-median: ER-M) and determined that toxicity is rare at concentrations below ER-L, occasional at concentrations between ER$\mathrm{L}$ and ER-M, and frequent at concentrations above ER-M. In the sediments from A, all studied concentrations are below ER-L (Cd : 1.2 ; Cu : 45 ; Pb : 100 ; Zn : 276 mg kg $^{-1}$, Alzieu and Quiniou, 2001) whereas, in those from P, copper is above this level. In the Arcachon harbour, Geffard et al. (2002) reported concentrations of metals in sediments in the same order of magnitude $\mathrm{Cd}: 0.65, \mathrm{Cu}: 41.6$ and $\mathrm{Zn}: 197 \mathrm{mg} \cdot \mathrm{kg}^{-1}$, as those displayed in Table 4.

The percentage of desorption of cadmium, higher in A than in $\mathrm{P}$, is in agreement with the higher redox potential and the lower $\mathrm{pH}$ found in A (Table 2), which promotes the desorption of metals (Geffard et al., 2005). Since cadmium in sediments is low compared to other metals (Table 4), the bioavailable quantities exerting toxic effects on oyster larvae are thus lower for cadmium than for copper or zinc.

Site A seems less influenced by metals (as suggested by the responses of larvae as well as the chemical determinations in sediments) than site P. Larvae exposed in site A presented a higher level of $\Sigma$ PAHs (and in particular naphthalene) and $\Sigma \mathrm{MN}$ than in P. Very few papers have focused on PAH accumulation and fingerprint in oyster larvae. PAHs are hydrophobic compounds that tend to adsorb rapidly on particles (Landrum and Robbins, 1990). Their concentration in the aqueous phase is very low, the lowest molecular weight and most water soluble compounds are the most bioavailable (Baumard et al., 1998). Naphthalene is a two-cycle compound which is soluble and is readily accumulated by the developing larvae at $\mathrm{A}$ and $\mathrm{P}$, as seen in Table 3 . Naphthalene and alkyl-naphthalenes are the main compounds constituting coal-tar. Coal-tar is used to treat wood in the oyster farming process and it could be a possible source of PAHs in the Bay of Arcachon, devoted to oyster culture and surrounded by timber-yards. The higher naphthalene and methyl-naphthalene concentrations in larvae from $\mathrm{A}$ than in $\mathrm{P}$ (Table 3) may be due to the mixture of waters coming from the Arcachon area in A. Moreover, A is located not far from a petrol pump for boats, implying that contamination from petrogenic sources cannot be ruled out. Larvae are directly exposed to $\mathrm{PAH}$ contamination present in the water column rather than to contamination adsorbed on sediments, the PAH concentration being the same in A and $\mathrm{P}$ (Table 5 : $\Sigma$ PAHs ca $1.5 \mathrm{mg} \mathrm{kg}^{-1}$ ). $\mathrm{PPAHs}$ in sediments are below the published values by Baumard et al. (1998) and Geffard et al. (2002) (i.e. 2.07 and $2.798 \mathrm{mg} \mathrm{kg}^{-1}$, 
respectively) for the Arcachon harbour. Therefore, in this study, the two sites do not seem to be submitted to a very strong PAH contamination.

The concentrations of PCBs in the sediments are below the detection limit of the analytical method, except for PCB 153. They are lower than ER-L guideline values (Alzieu and Quiniou, 2001) which are 0.05 for CB 153 and $0.5 \mathrm{mg} \mathrm{kg}^{-1}$ for the sum of the 7 considered congeners. PCBs do not seem to be present in concentrations that may evoke biomarker responses in larvae.

The biomarkers and chemical determinations in the larvae reveal some differences between the two chosen sites. Results could have been more significant if the comparison was made with a site located outside the Arcachon harbour. The two locations studied in the present paper seem to be also influenced by background contamination with other molecules than those measured in this work which may explain the high level of abnormal larvae observed at A and P (40 and 60\%, respectively). As a matter of fact, Devier et al. (2005), in a one-year monitoring survey of organic compounds and metals in blue mussels from the Arcachon Bay, suggested that background chemical contamination in the Arcachon harbour could be interpreted in terms of persistence of organotin compounds and PAHs and, to a lesser extent, of direct inputs of copper, related to the use of copper-based antifouling paints and to dockyard activities. The authors (Devier et al., 2005) reported TBT concentrations in mussel tissues ranging from $800 \mathrm{ng} \mathrm{g}^{-1}$ to $2400 \mathrm{ng} \mathrm{g}^{-1}$ (dry weight) in Arcachon harbour compared to a concentration of $30 \mathrm{ng} \mathrm{g}^{-1}$ in a reference site.

To conclude, many bio-assays, using sea-urchin or oyster larvae, have been recorded giving toxicity thresholds. The present study demonstrates that active bio-monitoring using biomarkers may be performed with oyster larvae. Moreover, the sensitivity of larvae to pollutants may be followed concomitantly in situ and in the laboratory, and chemical analyses may be performed in larvae and in the sediments collected under the larva containers. The duration of bio-monitoring is short $(48 \mathrm{~h})$, which is a great advantage, compared to other transplantation experiments (i.e. for adult mussels : from one to three months). Nevertheless, bio-monitoring must take place when the sea water temperature allows the good development of oyster larvae (from 19-20 to $25^{\circ} \mathrm{C}$ ) so that the quantity of biological material is sufficient to perform several chemical and biochemical analyses. In this study, the larvae which developed in the natural medium show different responses according to their immersion site $(\mathrm{A})$ or $(\mathrm{P})$, and these responses may be related to the chemical contamination of the environment. In a biomonitoring study a reference site is needed, far from background contamination, in order to obtain a clear pollution gradient; this site could be the entrance to the Bay of Arcachon. Further experiments are required to statistically validate the use of biomarkers in oyster larvae, and their links to chemical data obtained on living material and sediments.

\section{Acknowledgments}

This work was performed in the framework of a programme with the French Ministry of Environment (PNETOX program - Convention 08/2001, D4E-SRP). The technical assistance of Xavier Caisey was greatly appreciated 


\section{References}

Alzieu C, Quiniou F. Géodrisk - La démarche d'analyse des risques liés à l'immersion des boues de dragage des ports maritimes, in CD-ROM Geodrisk " Logiciel d'évaluation des risques liés à l'immersion des déblais de dragages des ports maritimes ». Coord. C. Alzieu, Ed. Ifremer; Juin 2001.

Andral B, Stanisière JY, Sauzade D, Damier E, Thébault H, Galgani F, Boissery P. Monitoring chemical contamination levels in the Mediterranean based on the use of mussel caging. Mar Pollut Bull 2004;49:704-12.

Baumard P, Budzinski $\mathrm{H}$. Internal standard quantification method and gas chromatography-mass spectrometry (GC-MS): a reliable tool for polycyclic aromatic hydrocarbon (PAH) quantification in natural matrices. Analusis 1997;25:246-52.

Baumard P, Budzinski H, Garrigues P. PAHs in Arcachon Bay, France: origin and biomonitoring with caged organisms. Mar Pollut Bull 1998;36:577-86.

Beiras R, Vasquez E, Bellasz J, Lorenzo JI, Fernandez N, Macho G, Mariño JC, Casas L. Sea urchin embryo bioassay for in situ evaluation of the biological quality of coastal seawater. Estuar Coast Shelf Sci 2001;52:29-32.

Canesi L, Viarengo A, Leonzio C, Filippelli M, Gallo G. Heavy metals and glutathione metabolism in mussel tissues. Aquat Toxicol 1999;46:67-76.

Damiens G, His E, Gnassia-Barelli M, Quiniou F, Roméo M. Evaluation of biomarkers in oyster larvae in natural and polluted conditions. Comp Biochem Physiol C 2004;138:121-8.

Damiens G, Mouneyrac C, Quiniou F, His E, Gnassia-Barelli M, Roméo M. Metal bioaccumulation and metallothionein levels in larvae of Crassostrea gigas. Environ Pollut 2006;140:492-9.

De Kock WC, Kramer KJM. Active biomonitoring (ABM) by translocation of bivalve molluscs. In: Kramer KJM, editor. Biomonitoring of coastal waters and estuaries. CRC Press, Boca Raton, FL; 1994.

Devier MH, Augagneur S, Budzinski H, Le Ménach K, Mora P, Narbonne JF, Garrigues P. One-year monitoring survey of organic compounds (PAHs, PCBs, TBT), heavy metals and biomarkers in blue mussels from the Arcachon Bay, France. J Environ Monit 2005;7:224-40.

Förstner U, Wittmann GTW. Metal pollution in the aquatic environment. SpringerVerlag, New-York; 1979.

Geffard O, His E, Budzinski H, Seaman M, Garrigues P. Qualité biologique de l'eau de mer évaluée in situ par le test embryo-larvaire de Crassostrea gigas et Mytilus galloprovincialis. C.R. Acad. Sci. Paris, Sciences de la vie/ Life sciences 2001;114955.

Geffard O, Budzinski H, His E, Seaman MLN, Garrigues P. Relationships between contaminant levels in marine sediments, and their biological effects on embryos of oysters, Crassostrea gigas. Environ Toxicol Chem 2002;21:2310-18.

Geffard O, Geffard A, Budzinski H, Crouzet C, Menasria R, Amiard JC, AmiardTriquet C. Mobility and potential toxicity of sediment-bound metals in a tidal estuary. Environ Toxicol 2005; 20:407-17.

His E, Seaman MNL, Beiras R. A simplification of the bivalve embryogenesis and larval development bioassay method for water quality assessment. Wat. Res 1997; 3:351-55. 
His E, Beiras R, Seaman MNL. The assessment of marine pollution. bioassays with bivalve embryos and larvae. Adv Mar Biol 1999;37:1-178

Landrum PF, Robbins JA. Bioavailability of sediment-associated contaminants to benthic invertebrates. In: Baudo R, Giesy JP, Muntau H, editors. Sediments : chemistry and toxicity of in-place pollutants. Lewis Publisher, Michigan. 8 ; 1990.

Lebesnerais C, 1985. Etude expérimentale de la digestion chez l'huître japonaise Crassostrea gigas (Thunberg). Thèse de doctorat, Université de Caen.

Long ER, McDonald DD, Smith SL, Calder FD. Incidence of adverse biological effects within ranges of chemical concentrations in marine and estuarine sediments. Environ Manage 1995;19,81-97.

Quiniou F, Toularastel F. Mesure de l'effet biologique de la qualité d'un milieu par le bio-essai embryo-larvaire de bivalve marin. ICES, Mar. Envir. Qual. Comm., 1991/E 26, Ref K; 1991.

Quiniou F, His E, Delesmont R, Caisey X. Bio-indicateur de la toxicité potentielle de milieux aqueux : bio-essai «développement embryo-larvaire de bivalve». Éd. Ifremer, Méthodes d'analyse en milieu marin ; 2005.

Roméo M, Hoarau P, Garello G, Gnassia-Barelli M, Girard JP. Mussel transplantation and biomarkers as useful tools for assessing water quality in the NW Mediterranean. Environ Pollut 2003 a;122:369-78.

Roméo M, Mourgaud Y, Geffard A, Gnassia-Barelli M, Amiard JC, Budzinski H. Multimarker approach in transplanted mussels for evaluating water quality in Charentes, France, coast areas exposed to different anthropogenic conditions. Environ Toxicol 2003 b;18:295-305.

Stebbing A, Akesson B, Calabrese A, Gentile JH, Jensen A, Lloyd R, 1980. The role of bioassays in marine pollution monitoring. Rapp P-V Reun CIESM Mediterr 1980;179:322-32.

Viarengo A, 1989. Heavy metals in marine invertebrates : mechanisms of regulation and toxicity at cellular level. Rev Aquat Sci 1989;1:295-317. 
Table 1. Protein concentrations, biomarker levels and copper content of in situ exposed larvae during July 2002.

\begin{tabular}{|c|c|c|}
\hline Biomarkers & A & $\mathrm{P}$ \\
\hline Proteins $\mathrm{mg} \mathrm{mL}^{-1}$ & 1.290 & 0.783 \\
\hline${\mathrm{AChE} \mathrm{nmol}^{-1} \mathrm{~min}^{-1} \mathrm{mg} \text { protein }}^{-1}$ & 24.537 & 13.020 \\
\hline TBARS nmol mg protein ${ }^{-1}$ & 1.92 & 3.79 \\
\hline MT $\mu g$ mg protein ${ }^{-1}$ & 4.30 & 3.52 \\
\hline
\end{tabular}


Table 2. Hydrological parameters in the waters from the two sites (A and P) from the Arcachon harbour. The parameters were measured with a WTM probe during June 2004.

\begin{tabular}{lll}
\hline Parameters & $\mathrm{A}$ & $\mathrm{P}$ \\
\hline Salinity (p.s.u.) & 31.6 & 31.6 \\
Temperature & $18{ }^{\circ} \mathrm{C}$ (morning) & $18{ }^{\circ} \mathrm{C}$ (morning) \\
& $21.2^{\circ} \mathrm{C}$ (afternoon) & $21.2^{\circ} \mathrm{C}$ (afternoon) \\
Dissolved $\mathrm{O}_{2}$ & $30.3 \%$ & $27.3 \%$ \\
$\mathrm{pH}$ & 7.53 & 8.10 \\
Redox potential & $-24 \mathrm{mV}$ & $-54 \mathrm{mV}$ \\
\hline
\end{tabular}


Table 3. Protein concentrations and biomarker levels of in situ exposed larvae during June 2004 (five pools in A and five pools in P). Copper, metallothionein (MT) and polycyclic aromatic hydrocarbons $(\mathrm{PAH})$ concentrations were determined in one pool of larvae in each case. $\Sigma$ PAHS = sum of PAHs; $\Sigma \mathrm{MN}=$ sum of Methyl-Naphthalenes; $\Sigma \mathrm{MP}$ = sum of Methyl-Phenanthrenes; results are in $\mathrm{ng} \mathrm{g}^{-1}$ (dry weight). * shows that the values of $\mathrm{P}$ are significantly different from those of A at $P<0.05$ (Student's test). D.L.: Detection limit.

\begin{tabular}{|c|c|c|}
\hline Biomarkers and pollutants & A & $\mathrm{P}$ \\
\hline Proteins $\mathrm{mg} \mathrm{mL}^{-1} ; \mathrm{n}=5$ & $3.68 \pm 1.29$ & $4.31 \pm 0.70$ \\
\hline AChE nmol ${ }^{-1} \min ^{-1} \mathrm{mg}_{\text {protein }}{ }^{-1} ; \mathrm{n}=5$ & $8.76 \pm 2.62$ & $7.50 \pm 2.31$ \\
\hline CAT $\mu \mathrm{mol}^{-1} \mathrm{~min}^{-1} \mathrm{mg}$ protein ${ }^{-1} ; \mathrm{n}=5$ & $4.62 \pm 0.49$ & $4.68 \pm 1.63$ \\
\hline $\mathrm{GST}_{\mathrm{nmol}}^{-1} \mathrm{~min}^{-1} \mathrm{mg}$ protein ${ }^{-1} ; \mathrm{n}=5$ & $577.6 \pm 129.5$ & $869.1 \pm 39.3^{*}$ \\
\hline TBARS nmol ${ }^{-1} \mathrm{mg}$ protein $^{-1} ; \mathrm{n}=5$ & $2.02 \pm 0.11$ & $2.74 \pm 0.19 *$ \\
\hline MT $\mu g$ mg protein ${ }^{-1}$ or $\mu g^{-1}$ w.w. ; 1 pool. & 9.38 or 125.1 & 11.82 or 157.6 \\
\hline $\mathrm{Cu}$ : ng mg protein ${ }^{-1}$ or ng $\mathrm{g}^{-1}$ w.w.; 1 pool & 32.7 or 214.5 & 35.8 or 234.9 \\
\hline Acenaphtylene & 2 & 2 \\
\hline Acenaphtene & 6 & 9 \\
\hline Naphthalene & 511 & 331 \\
\hline Phenanthrene & $<$ D.L. & $<$ D.L. \\
\hline Anthracene & $<$ D.L. & $<$ D.L. \\
\hline Fluoranthene & 9 & 7 \\
\hline Pyrene & 11 & 7 \\
\hline Benzo(a)anthracene & $<$ D.L. & $<$ D.L. \\
\hline Chrysene + triphenylene & 5 & 10 \\
\hline Benzo(b)fluoranthene & 3 & 3 \\
\hline Benzo(k) fluoranthene & $<$ D.L. & 1 \\
\hline Benzo(e)Pyrene & 4 & 3 \\
\hline Benzo(a)Pyrene & $<$ D.L. & 2 \\
\hline Indeno(1,2,3-cd)Pyrene & $<$ D.L & $<\mathrm{D} . \mathrm{L}$ \\
\hline diBenzo(a,h) + dibenzo(a,c)anthracene & $<$ D.L & $<\mathrm{D} . \mathrm{L}$ \\
\hline Benzo(g,h,i)Perylene & 13 & 9 \\
\hline$\Sigma \mathrm{PAHs}$ & 566 & 384 \\
\hline ¿MN (Methyl-Naphthalenes) & 215 & 123 \\
\hline ¿MP (Methyl-Phenanthrenes) & $<$ D.L. & $<$ D.L. \\
\hline
\end{tabular}


Table 4. Metal concentrations ( $\mathrm{mg} \mathrm{kg}^{-1}$ dry weight) in the sediments from $\mathrm{A}$ and $\mathrm{P}$ locations in the harbour of Arcachon and in a standard reference sediment (MESS-2, marine sediment, National Research Council Canada). Differences between metal concentrations between the two locations (A and P) as well as differences between metal concentrations in sediments and in acid-treated sediments were evaluated using the Mann-Whitney test $(* P<0.05$ or $* * P<0.01)$.

\begin{tabular}{lllllll}
\hline Metal & $\begin{array}{l}\text { Reference sample } \\
\text { Certified values Our values }\end{array}$ & $\mathrm{A}$ & $\begin{array}{l}\mathrm{A} \\
\text { treated }\end{array}$ & $\mathrm{P}$ & $\begin{array}{l}\mathrm{P} \\
\text { treated }\end{array}$ \\
\hline $\mathrm{Cd}$ & $0.24 \pm 0.01$ & $0.25 \pm 0.02$ & $0.61 \pm 0.07$ & $0.40 \pm 0.02^{*}$ & $0.58 \pm 0.03$ & $0.52 \pm 0.04^{*}$ \\
$\mathrm{Cu}$ & $39 \pm 2$ & $41 \pm 2$ & $35 \pm 2$ & $32 \pm 3$ & $65 \pm 1^{* *}$ & $60 \pm 5$ \\
$\mathrm{~Pb}$ & $21.9 \pm 1.2$ & $17.3 \pm 0.4$ & $34 \pm 3$ & $36 \pm 6$ & $42 \pm 5$ & $45 \pm 6$ \\
$\mathrm{Zn}$ & $172 \pm 16$ & $160 \pm 20$ & $178 \pm 11$ & $169 \pm 10$ & $229 \pm 14^{*}$ & $220 \pm 13$ \\
\hline
\end{tabular}


Table 5. PAH concentrations in the standard reference sediment IRM-109, the lower and higher values are given by the supplier (Community Bureau of Reference, Commission of European communities) and in the sediments from the two locations (A and $\mathrm{P}$ ) in the harbour of Arcachon.

\begin{tabular}{|c|c|c|c|c|c|}
\hline $\begin{array}{l}\text { PAHs } \\
\text { mg kg}^{-1} \text { (dry weight) }\end{array}$ & $\begin{array}{l}\text { Lower } \\
\text { value }\end{array}$ & $\begin{array}{l}\text { Higher } \\
\text { value }\end{array}$ & Our values & A & $\mathrm{P}$ \\
\hline Acenaphtene & & & & $<0.05$ & $<0.05$ \\
\hline Naphthalene & & & & $<0.05$ & $<0.05$ \\
\hline Phenanthrene & & & & 0.07 & 0.05 \\
\hline Anthracene & 1.15 & 1.73 & 1.53 & $<0.05$ & $<0.05$ \\
\hline Fluoranthene & 19.7 & 29.4 & 22.65 & 0.21 & 0.25 \\
\hline Pyrene & & & & 0.25 & 0.22 \\
\hline Benzo(a)anthracene & 6.7 & 9.26 & 7.63 & 0.16 & 0.18 \\
\hline Chrysene & & & & 0.16 & 0.16 \\
\hline Benzo(b)fluoranthene & & & & 0.16 & 0.13 \\
\hline Benzo(k)fluoranthene & & & & 0.08 & 0.07 \\
\hline Benzo(a)pyrene & 4.25 & 5.94 & 4.96 & 0.16 & 0.13 \\
\hline Indeno(1,2,3-cd)pyrene & 3.45 & 5.47 & 4.07 & 0.13 & 0.09 \\
\hline Dibenzo(ah)anthracene & & & & $<0.05$ & $<0.05$ \\
\hline Benzo(ghi)perylene & 2.65 & 4.51 & 4.28 & 0.17 & 0.23 \\
\hline$\Sigma$ PAHs & & & & 1.55 & 1.51 \\
\hline
\end{tabular}


Table 6. PCB concentrations in the harbour reference sediment 536, the lower and higher values are given by the supplier (International Atomic Energy Agency : I.A.E.A.) and in the sediments from the two locations (A and P) in the harbour of Arcachon.

\begin{tabular}{llllll}
\hline $\begin{array}{l}\text { PCBs } \\
\mathrm{mg} \mathrm{kg}^{-1} \text { (dry weight) }\end{array}$ & $\begin{array}{l}\text { Lower } \\
\text { value }\end{array}$ & $\begin{array}{l}\text { Higher } \\
\text { value }\end{array}$ & Our values & $\mathrm{A}$ & $\mathrm{P}$ \\
\hline PCB 28 & 39 & 49 & 35 & $<0.02$ & $<0.02$ \\
PCB 52 & 34 & 42 & 36 & $<0.01$ & $<0.01$ \\
PCB101 & 40 & 48 & 45 & $<0.01$ & $<0.01$ \\
PCB118 & 25 & 31 & 28 & $<0.01$ & $<0.01$ \\
PCB138 & 23 & 31 & 27 & $<0.01$ & $<0.01$ \\
PCB153 & 46 & 54 & 48 & 0.01 & 0.01 \\
PCB180 & 20 & 24 & 23 & $<0.01$ & $<0.01$ \\
SPCBs & & & & 0.01 & 0.01 \\
\hline
\end{tabular}


Fig. 1. Location of immersion flasks containing Crassostrea gigas larvae at the entrance (A) of the harbour of Arcachon (S.W. France, along the Atlantic coast) and inside the harbour $(\mathrm{P})$.

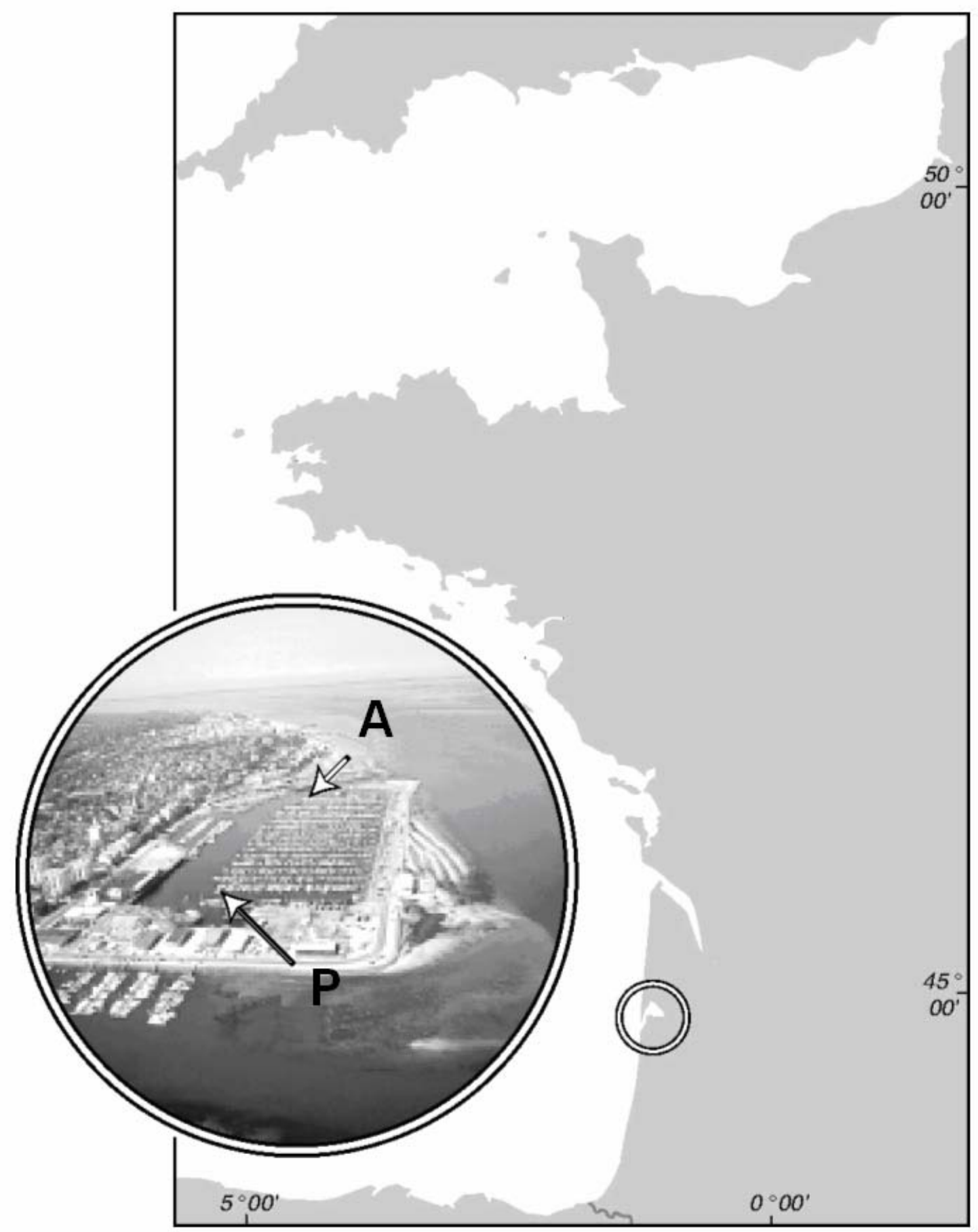


Fig. 2. Sensitivity of Crassostrea gigas larvae to $\mathrm{CuSO}_{4}, 5 \mathrm{H}_{2} \mathrm{O}:$ A) percentage of larvae blocked at the embryo stage $\square$; larvae with abnormal mantle or shell $\boldsymbol{\square}$; normal larvae $\mathbb{N}$

B) Graphical determination of EC50.

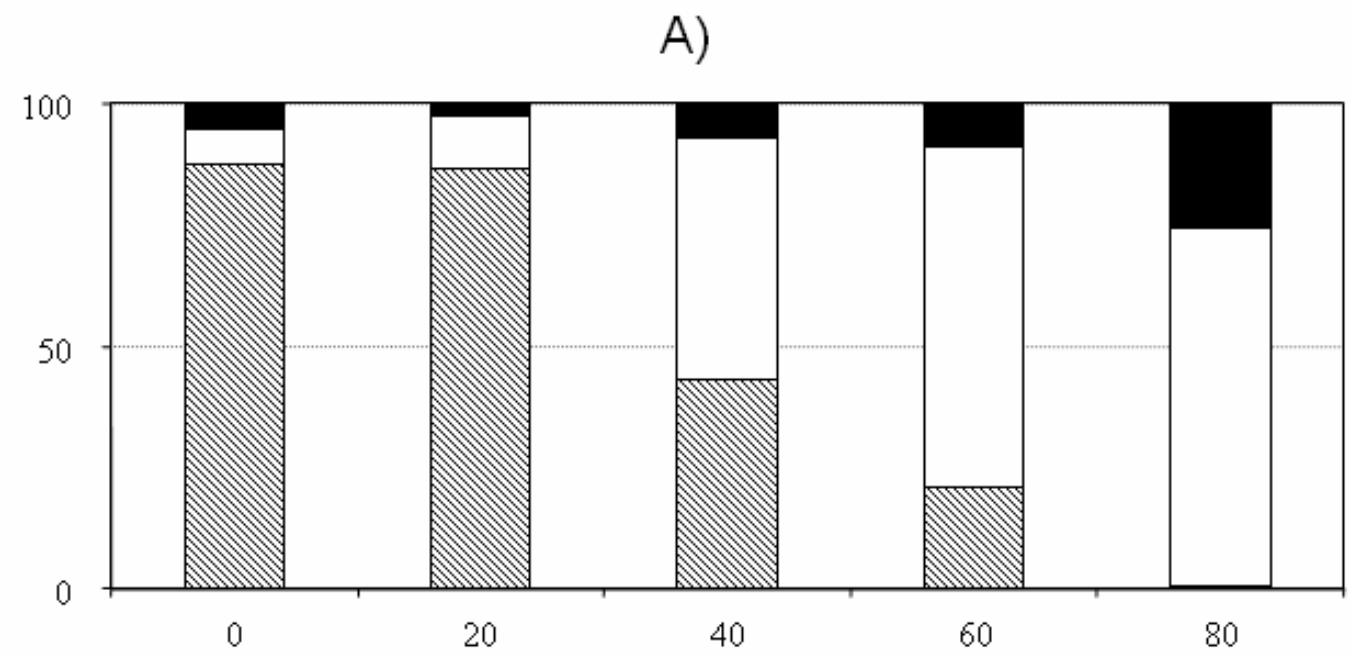

B)

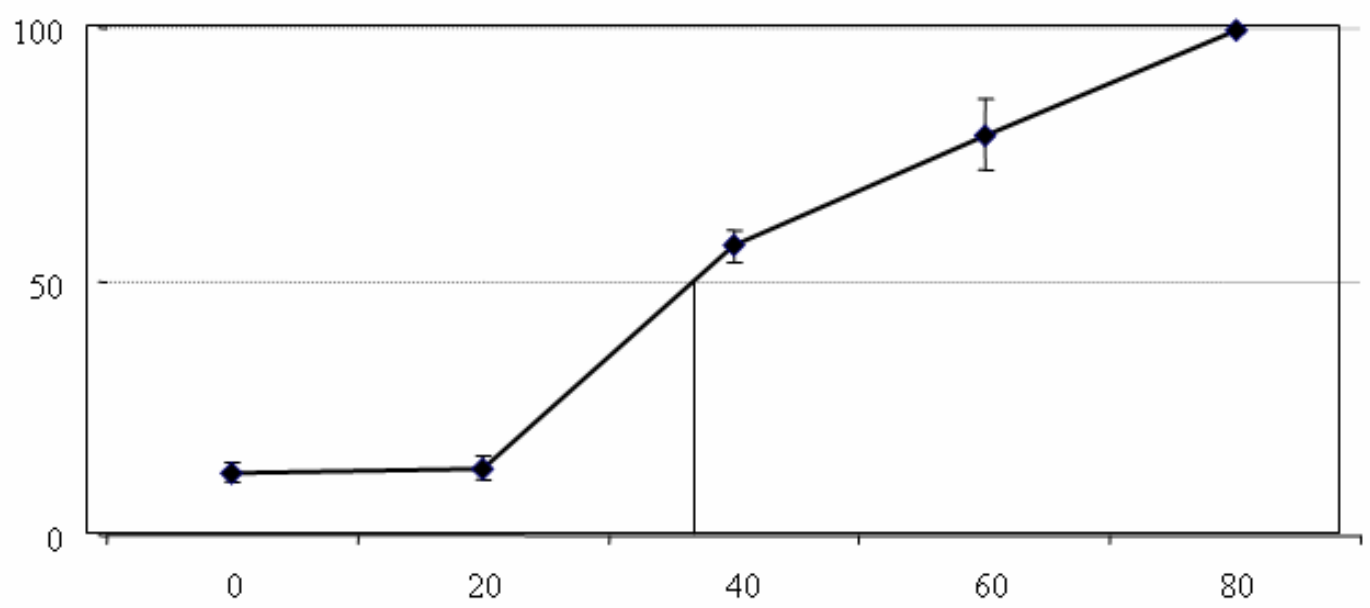

$\mathrm{CuSO}_{4}, \mu \mathrm{g} \mathrm{l}{ }^{-1}$ 
Fig. 3. A) Percentage of abnormal larvae (same symbols as in Fig. 2A) in larvae from the containers immersed in A (entrance to the Arcachon harbour) and $\mathrm{P}$, the percentage of control larvae comes from the toxicity test of Fig. 2B ; B) Total percentage of abnormal larvae according to immersion sites.

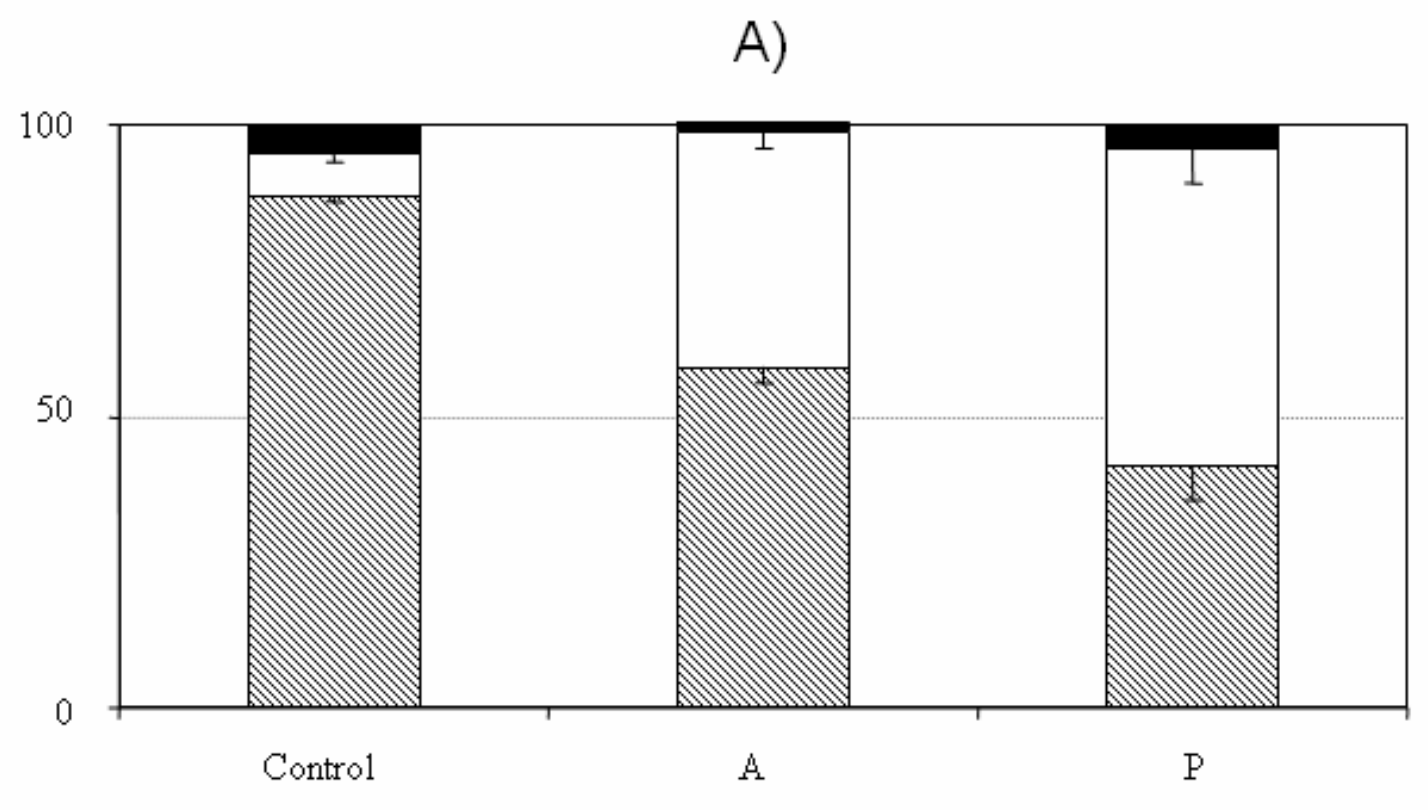

B)

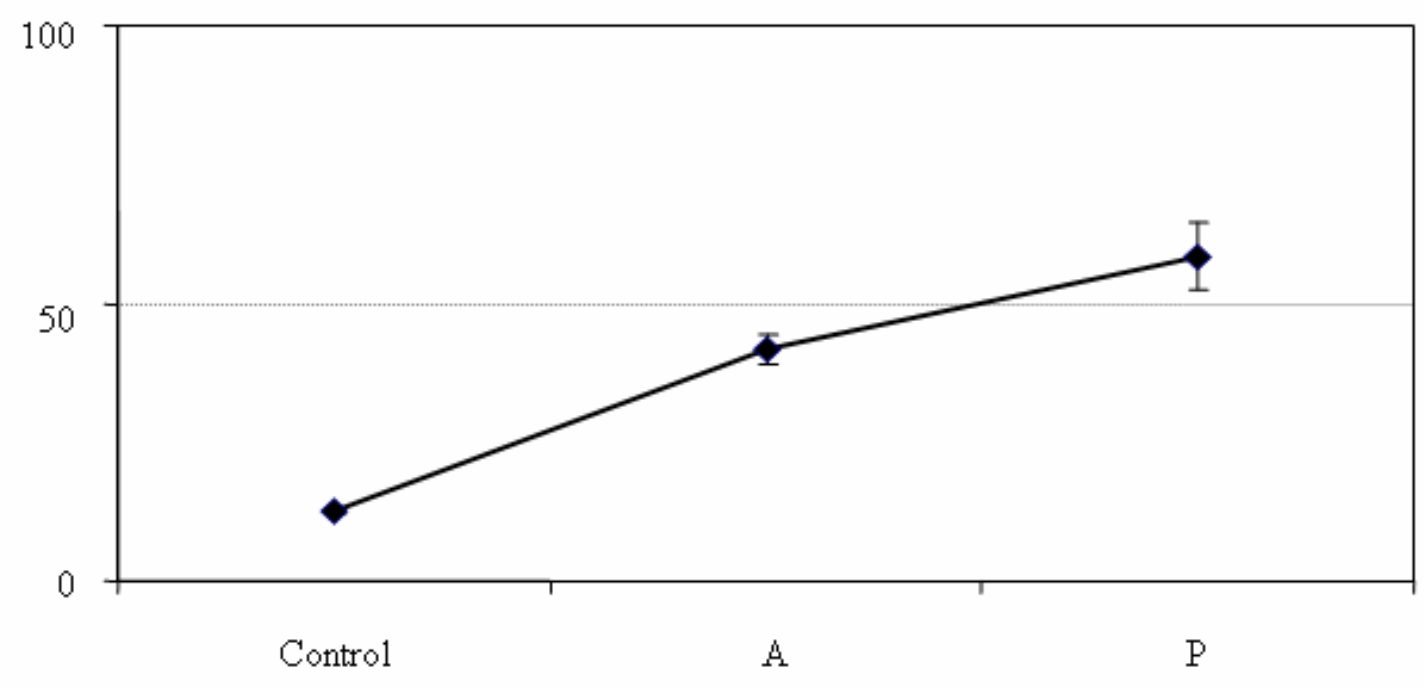

